\title{
Diversity, dilemmas and transformation in Post-Compulsory Education: an introduction to the special issue on work based research
}

Geoffrey Elliott

Address for Correspondence:

Professor Geoffrey Elliott

Director of Regional Engagement

University of Worcester

Worcester WR2 6AK

g.elliott@worc.ac.uk

As governments recognize the central place of post-compulsory education in regenerating and modernizing the economic and social fabric of society (BIS 2008), it is appropriate for us as educational researchers to question whether this recognition beckons a different role for research in post-compulsory education. Much of this research is work based, using a broad interpretation of this term, and the majority of articles received by this journal (though the proportion published is a lower one) reflect this balance. Work based research in education poses particular challenges for the researcher and the practitioner, whether the focus is practitioner research, in which case the dilemmas can centre on potential role conflict between practitioner and researcher roles, or whether the work based research is observational - analyzing others' professional practice, in which case the dilemmas can centre on power relations between researcher and researched, the politics of research, and ethical questions around care for participants and the degree of their involvement or noninvolvement in the total research enterprise. These issues have been recently summarized by Beckett $(2009,3)$ in her work on teachers and academic partners working together in school settings: 
... the responsibility on academic partners is no small matter, especially where there was no experience in practitioner research. There is the need to establish respectful and trustworthy relationships with staff and students as well as the wider community; acknowledge the school's work and its obligations, legislative and otherwise; recognize the constraints operating on teaching in tough schools, including the significant barriers to learning; help teachers communicate their personal, professional and social responsibilities; articulate our social vision and values; and develop critical thinking / sociological analyses and a shared vocabulary.

As Beckett notes, this requires a different way of working, drawing teachers away from the isolation of their classrooms to become part of an enquiry community, but also introducing some uncertainty given the researchers' need to engage with senior management. These changes however should not be seen as simply positive or negative, but indicative of a wider possibility of the transformative impact of work based research incorporating the workplace (school, college, university), the academy (university academic requirements and processes) and the practitioner (teacher, lecturer, ancillary support worker) in a contract of reflexivity, empowerment, autonomy, agency, knowledge building, consciousness raising, challenge, and crucially and critically, theorization and theory-building placed at the centre of the enterprise of learning and teaching through an organic and inter-dependent relationship with research.

Many work-based research settings, not least post-compulsory education, are populated by professionals who are regulated and influenced in their professional lives by sets of professional codes and practices. The term 'practitioner' has developed as a kind of quasi-professional concept, suggesting a mode of working that is characterized by thoughtful and reflexive action. For the work-based researcher, how 
professionals and practitioners regard themselves and their work situation is a vital and rich source of data. A number of studies (for example, Elliott 1996; 1998) have found that practitioners and professionals, in the face of growing managerialism in their professional and occupational environment, the introduction of narrow and prescriptive occupational standards, and of the demands made by policy shifts towards increased accountability, find it necessary to affirm the territory of their expertise, which is frequently located in their subject or vocational background.

The starting point of transformative work-based practice and work-based research is the recognition that, in order to be meaningful for the practitioner, conceptualizations of work should be grounded in practitioners' own understandings and experience of their working practices. It should equally reflect the range of these practices as well as their epistemological and ethical basis. It should reflect a phenomenological perspective towards organizations, which recognizes the centrality of understanding individuals' orientations (Maslow 1954) and that 'organisations are to be understood in terms of people's beliefs about their behaviour within them' (Greenfield 1975, 83). It should also be capable of supporting theoretical and political opposition to attempts to redefine practitioners' shared values, which requires a micro-political perspective that recognizes the different interests, biographies, careers, priorities, subjects, status and orientations of practitioners. It also requires a moral and values orientation, since it is only through the 'grounding of our actions in our values that we can recognise the nature of the competing rationalities we face and find means of coping with them, whether as managers or those being managed' (Bennett et al. 1992, 15). It requires a political stance since it is centrally concerned with the development of a critical consciousness to a level where individuals can achieve a sufficient degree of social and political awareness to understand contradictions within society and work to transform it, what Freire $(1972,16)$ has termed 'conscientisation'. It requires a strong ethical framework for action, based on a duty and responsibility of care for 
participants, that avoids traditional notions of researcher bias and imposition of academy values onto practitioners.

Elliott (1991), writing in the context of action research for educational change, identified a number of dilemmas which can be generalized to all work-based research settings. These include:

- Encouraging others to critique one's professional practice;

- Gathering difficult data;

- Sharing data with professional peers both inside and outside the organization, and Blurring of the practitioner-researcher role.

A further dilemma which has, in my view, undoubtedly blunted the development and application of reflective practice, is reluctance to produce case studies of researcher's own work based research and practices.

Each of these dilemmas, if left unresolved, has the potential to thwart even the most experienced work-based researcher. In general, careful thought, planning, and consultation with appropriate colleagues and managers in the workplace should point to ways of resolving most of these tensions. However, we should guard against easy solutions that constrain professionalism and legitimate authority, privacy and territoriality. Helen Simons has powerfully argued the case for a distinctive methodology of insider research/evaluation which rests 'upon the possibility of dismantling the value structure of privacy, territory and hierarchy, and substituting the values of openness, shared critical responsibility and rational autonomy' (Simons 1985).

There is an ongoing debate amongst researchers about the extent to which findings from small scale work based studies can be generalized. This is a controversial debate 
which polarizes opinion, however a number of writers have noted the powerful potential for small scale research in the qualitative tradition to:

- tutor our judgement (Stenhouse 1979)

- highlight internal contradictions in policy formulation and implementation (Finch 1988)

- provide working recipes for an understanding of the abstract properties of social life (Rock 1979)

- give a detailed understanding of the local context in which innovations are being attempted (Crossley and Vulliamy 1984)

- tap the quiddity, the uniqueness of particular cultures, contexts and personalities (Hurst 1987)

- be a powerful management tool that is highly sensitive to the perspectives of those directly affected by policies and procedures (Elliott 1996), and

- connect research with the everyday world through the use of fuzzy generalization (Bassey 1998).

In reviewing the contributions to this special issue it became evident that themes of complexity and diversity dominate. It is clear to me that work based research has very significant potential in unlocking the previously closed worlds of the workplace and, often through the lens of participants themselves, has the power to give insight and clarity to otherwise concealed or obscured phenomena.

The diversity of professional identities in further education is well illustrated by the first paper in this Issue by Rebecca Turner, Liz McKenzie, and Mark Stone. Themselves spanning the worlds of further (Truro College) and higher education (University of Plymouth), the authors explore and examine the professional identities of those teaching higher education students in further education colleges. Professional identity is seen by them and others as linked closely to the culture of an organisation, 
social/professional interactions and experience, self perception, individual knowledge and skills. In the case of FE lecturers, they often enter teaching as established professionals in their field of expertise, thus importing external professional perspectives. Given this complex and diverse range of influences, Turner, McKenzie and Stone investigate the impact of expanding HE provision on the professional identities of a group of lecturers working within four FE colleges in south west England.

The second paper is a reflection on the author's journey in a work-based research project while completing his $\mathrm{PhD}$ at a large Australian university. John Kenny, from the University of Tasmania, explores, through a case study method, dilemmas that arose as he studied strategic change in the university and how his role evolved from that of a 'change agent' working as part of a project team to that of a researcher. Kenny discovers complexity and even unpredictability during the course of his work based research project, which lead him to draw out implications for organisational managers and work based researchers. He argues an interesting distinction between work based learning, which he characterises as internally focused, and work based research, characterised as externally focused, so whilst also situated within the prevailing body of knowledge also shared with the broader academic community and having value beyond the institutional boundary.

The article by Sue Maguire and Prue Huddlestone of the University of Warwick simply titled 'Where do young people work?' is significantly one of the first published studies of the 'jobs without training' group. The authors present findings from their Economic and Social Research Council funded study of young people who are in full-time work and not in receipt of training which reaches the standard of an NVQ level 2 (or above) qualification. Using a qualitative methodology, the study seeks an in-depth understanding of the background, motivations and attitudes of young people and their parents/carers, and of employers' rationale and motivation for recruiting young 
people into jobs without training. They observe both the heterogeneity of employers' needs in terms of what they might be looking for in the skills and attributes of young people coming to them for employment, and at the same time the diversity of the group classified as young people in jobs without training. Against the UK government policy intention that all young people remain in some form of accredited education or training up to the age of 18 by 2015, the authors identify significant challenges to achievement of this ambitious goal.

The next article, by Andrea Laczik and Caroline White, also from the University of Warwick, examines employer engagement within the UK 14-19 Diploma development - a package of employer designed Diplomas for 14-19 year olds linked to different industrial and commercial sectors. The authors draw upon three pieces of research: a review of Diploma development and two employer consultation studies belonging to the latest phase of Diploma development - the Diplomas in Humanities and Social Sciences and Languages and International Communications. Laczik and White argue that meeting the needs of employers in qualification design is problematic as employers are a heterogeneous group bringing a range of different views, ideas and contributions to the process. They also highlight a possible mismatch between policy makers' expectations from employers at macro level, and what in fact happens at local, micro level due to personal and economic circumstances, companies' demands and the economic climate.

Writing in a Jordanian context, Aieman Ahmad Al-Omari of the Hashemite University, and Kayed M. Salameh of Yarmouk University, examine faculty members and academic administrators' perspectives on strategic planning effectiveness in Jordanian universities. Their favoured method is the questionnaire, which enables them to sample 338 faculty members and 183 academic administrators. A Strategic Planning Effectiveness Survey was developed, consisting of 42 items distributed on 
five dimensions: Importance of strategic planning, level of involvement, depth of implementation, institutional planning model, and institutional decision making. According to the authors, the 'depth of implementation' dimension appeared to have the most important impact on strategic planning effectiveness. They also conclude that participants' perspectives of strategic planning effectiveness differed significantly according to their job role.

Erica Smith, of the University of Ballarat, describes how young people are increasingly adopting dual identities - as worker and learner - during the long transition from fulltime student to full-time worker. She notes that in Australia as in many other countries, most school students have part-time jobs through school and university, and highlights the significance of these part-time work roles in paving the way for transition to full-time work and learning about work. In particular Smith speculates on how these complex and often underplanned arrangements - including part-time study carried out by young workers through traineeships and apprenticeships - may well be redefining how young people think about education and jobs and how they conceptualise their movement into the full-time workforce. The article powerfully argues that the former idea of a school-to-work transition is no longer valid and that young people regard study and work as ongoing parts of their lives.

Elda Nicolou-Walker of Queens University Belfast and Kathy Lavery (Independent Researcher) report on a work-based project concerned with the impact 'Lean Manufacturing' may have on Health and Safety performance and education within an Engineering Company. The focus of the project is to determine through work-based research the employee perception on Health and Safety: has it changed (either 
positively or negatively), as a consequence of implementing 'Lean Manufacturing'. The contribution demonstrates the benefit of a mixed methods approach to work based learning, and in particular the strengths of observation and interviews in uncovering workplace practices and employee perceptions respectively.

Bronwen Maxwell, of Sheffield Hallam University, in her mixed methods study of inservice learning and skills sector trainees, argues the case for more multi-dimensional conceptual and practice development continua, that reflect more accurately the subtleties and complexities of trainee development, allowing for different starting and end points, and accommodating varied work contexts. Her work is a robust attempt to address widely perceived weaknesses in current practice in trainee preparation and training, and to address the apparent lack of awareness in official prescriptions about the processes of professional development. She concludes that initial teacher education in the learning and skills sector, especially support for trainees, would be enhanced by the more sophisticated understanding of the commonalities and diversity of trainees' journeys that can be gained from using the development continua.

In 'Performativity and symbiosis: the gap between policy and practice in the English Further Education system' Kevin Orr of the University of Huddersfield returns us yet again to the idea of complexity by citing Coffield et al who created an 'organigram' of the sector which they describe as looking "[M]ore like the chart of the internal wiring of an advanced computer than the outline of a 'streamlined', coherent sector" (Coffield et al 2008, 15-17). Orr draws upon existing literature, policy documentation as well as qualitative data to demonstrate how a symbiosis of performativity has evolved from government reforms, perpetuating the gap between policy and practice. Drawing on the data from his sample colleges, Orr finds that although respondents to the research acknowledged that the CPD initiative was still relatively new, none indicated that it had made a significant difference to practice in institutions over twelve months 
after its introduction, though it had been experienced in managerialist accountability. Orr draws upon a Bourdieuian analysis (Bourdieu 1990) to conceptualise the construction and implementation of education policy and how performativity can be internalized. His contribution highlights the limitations of top-down, outcomes-led policymaking and how this leads to a policy-practice gap when colleges have little control over setting their own collective priorities in a rational rather than performative manner.

Judging from the papers in this special issue, there is much evidence to support the view that small scale work based research can enhance our understanding of the complex and diverse social world of work. The range and depth of research on workplaces in post-compulsory education is, I believe, indicative of a general growth in awareness of the potential of work based research to illuminate educational research questions, whether the setting is the classroom, the department or unit, or the wider organization. Similarly, work based research itself draws upon a diverse variety of theories, methodologies, and methods, and a good number of exponents of work based research find a strong rationale for adopting an eclectic mixed methods approach. Some detractors of practitioner work based research make claims of the kind: 'research is supposed to carry a level of expertise that work based researchers often don't have' (comment overheard at a recent education conference). However statements of this kind harmfully undermine the central involvement of practitioners in researching their own workplace, and deny the capacity of collaborative research in post-compulsory education and elsewhere to generate really useful pedagogical insights and new educational knowledge and theory. I hope that the articles in this issue go some way towards justifying the claim that work based research has much that is unique and valuable to contribute to research in post compulsory education.

\section{References}


Argyris, C. And Schon, D. 1974. Theory in practice: increasing professional effectiveness. San Francisco: Jossey Bass.

Barton, T. 2008. Understanding practitioner ethnography, Nurse Researcher 15, no. 2:7-18.

Bassey, M. 1998. Fuzzy generalisation: an approach to building educational theory. Paper presented to British Educational Research Association annual conference, 27 August, Queen's University Belfast.

Beckett, L. 2009. Teachers and academic partners working together: organic partnerships. Paper presented to British Educational Research Association annual conference, 4 September, University of Manchester.

Bennett, N., M. Crawford, and C. Riches (eds.) 1992. Managing Change in Education London: Paul Chapman/Open University Press.

Bourdieu, P. 1990. The Logic of Practice Stanford: Stanford University Press.

Coffield, F.; Edward, S.; Finlay, I.; Hodgson, A.; Spours, K. \& Steer, R. 2008. Improving Learning, Skills and Inclusion: The impact of policy on post-compulsory education. Abingdon: Routledge.

Crossley, M., and G. Vulliamy. 1984. Case study research methods and comparative education. Comparative Education 20, no. 2: 193-207.

Department of Business, Innovation and Skills 2008. Higher Education at Work - high skills: high value. London: HMSO

Elliott, G. 1996. Crisis and change in vocational education and training. London: Jessica Kingsley.

Elliott, G. 1998. Teaching in post-compulsory education: profession, occupation or reflective practice? Teachers and teaching 4 no.1: 161-75 ISSN 13540602. Reprinted in: Teachers and trainers: Theories of action. Deakin University Faculty of Education Reader, 1999.

Elliott, J. 1991. A model of professionalism and its implications for teacher education. British Educational Research Journal 17, no. 4: 309-18. 
Finch, J. 1988. Ethnography and public policy. In Education, training and the new vocationalism, ed. A. Pollard, J. Purvis and G. Walford. Milton Keynes: Open University Press.

Freire, P. 1972. Pedagogy of the oppressed. Trans. Myra Bergman Rumos. Harmondsworth: Penguin.

Greenfield, T. 1975. A theory about organizations: A new perspective and its implications for schools. In Administering education: International challenges, ed. M. Hughes. London: Athlone Press of the University of London.

Hurst, P. 1987. The methodology of qualitative research. International Journal of Educational Development 7, no. 1: 69-72.

Maslow, A. 1954. Motivation and personality. New York: Harper and Row.

Rock, P. 1979. The making of symbolic interactionism. London: Macmillan.

Simons, H. 1985. Against the rules: Procedural problems in school self-evaluation Curriculum Perspectives 5, no. 2: 2-5. 